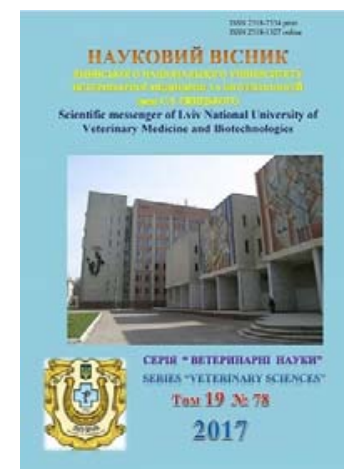

Науковий вісник Львівського національного університету ветеринарної медицини та біотехнологій імені С.З. Гжицького

Scientific Messenger of Lviv National University of Veterinary Medicine and Biotechnologies

doi:10.15421/nvlvet7827

ISSN 2518-7554 print

ISSN 2518-1327 online

$\underline{\text { http://nvlvet.com.ua/ }}$

УДК 363.2:577.115.16:546.41.18

\title{
D-вітамінний статус корів та їхніх телят у ранній постнатальний період у зимово-стійловий період
}

\author{
Л.Л. Юськів \\ yuskiv_11@ukr.net \\ Львівський національний університет ветеринарної медицини та біотехнологій імені С.3. Гжицького, \\ вул. Пекарська, 50, м. Львів, 79010, Україна
}

\begin{abstract}
У статті наведено дані щзодо вмісту активного метаболіту вітаміну $\mathrm{D}_{3}-25 \mathrm{OHD}_{3}$, концентрації кальцію, фосфору, магнію та активності лужної фосфатази в крові корів та їхніх телят у ранній постнатальний період.

Дослід проведено на високопродуктивних коровах-аналогах української чорно-рябої молочної породи у період сухостою і після отелення та отриманих від них телятах. Дослід проводили у зимово-стійловий період у Державному підприємстві «Дослідне господарство» «Пасічна» Інституту кормів та сільського господарства Поділля НААН.

Для біохімічних досліджень від корів брали кров з яремної вени на 5-7-й день після отелення. Кров від телят брали на 5-7-й і 28-30-й дні після народження. Встановлено, щэо у зимово-стійловий період вміст 25-гідроксихолекальциферолу у крові телят 5-7-денного віку знаходився у межах від 29 до 34 нмоль/л. Встановлено динаміку змін вмісту кальцію загального і його фракцій, фосфору неорганічного, магнію та активності лужної фосфатази та ії ізоензимів у крові телят від 5-7до 28-30-денного віку. Концентрація 25-гідроксивітаміну $D_{3}$ у крові телят у перші дні після народження була нижчою, а концентрація кальиію і неорганічного фосфору - вищою, порівняно до їх значень у крові матерів у післяотельний період.При цьвому встановлено, щео активність лужної фосфатази у сироватці крові телят була вищою, порівняно до ії значення у сироватиі крові матерів. Збільшення активності лужної фосфатази у сироватиі крові телят виражено більшою мірою за рахунок ї̈ кісткового ензиму.
\end{abstract}

Ключові слова: корови, телята, вітамін $D_{3}$, метаболізм, кров, 25-гідроксихолекальциферол.

\section{D-витаминный статус коров и их телят в ранний постнатальный период в зимне-стойловый период}

\author{
Л.Л. Юськив \\ yuskiv_11@ukr.net
}

Львовский национальный университет ветеринарной медицины и биотехнологий имени С.3. Гжицкого, ул. Пекарская, 50, г. Львов, Украина

В статье приведены данные по содержанию активного метаболита витамина $D_{3}-25 O H D_{3}$, концентрации кальиия, фосфора, магния и активности щелочной фосфатазы в крови коров и телят в ранний постнатальный период.

Опыт проведено на высокопродуктиных коров-аналогах украинской черно-рябой молочной породы в период сухостоя и после отела и полученных от них телят. Опыт проводили в зимне-стойловый период в Государственном предприятии «Опытное хозяйство» «Пасична» Института кормов и сельского хозяйства Подолья НААН.

Для биохимических исследований от коров брали кровь из яремной вены на 5-7-й день после отела. Кровь от телят брали на 5-7-й и 28-30-й дни после рождения. Установлено, что в зимне-стойловый период концентрачия 25гидроксиколекальичиерола в крови телят 5-7-дневного возраста была в пределах от 29 до 34 нмоль/л. Установлено динамику изменений содержания кальиия общего и его фракиий, фосфора неорганического, магния и активности щелочной фосфатазы и ее изоэнзимов в крови телят от 5-7- до 28-30-дневного возраста.

Citation:

Yuskiv, L.L. (2017). D-vitamin status of cows and their calves in the early postnatal period during the winter-stall period. Scientific Messenger $L N U V M B, 19(78), 136-140$ 
Концентрация 25-гидроксивитамина $D_{3}$ в крови телят в первые дни после рождения была ниже, а кониентрация кальция и неорганического фосфора - выше по сравнению с их значением в крови матерей в послеродовой период. При этом установлено, что активность щуелочной фосфатазы в сыворотке крови телят была выше, по сравнению с ее значением в сыворотке крови матерей. Увеличение активности щзелочной фосфатазы в сыворотке крови телят выражено в большей степени за счет ее костного энзима.

Ключевые слова: коровы, телята, витамин D3, метаболизм, кровь, 25-гидроксихолекальциферол.

\title{
D-vitamin status of cows and their calves in the early postnatal period during the winter-stall period
}

\author{
L.L. Yuskiv \\ yuskiv_11@ukr.net \\ Stepan Gzhytskyi National University of Veterinary Medicine and Biotechnologies Lviv, \\ Pekarska Str., 50, Lviv, 79010, Ukraine
}

The article presents data about the content of active metabolite of vitamin $\mathrm{D}_{3}-25 \mathrm{OHD}_{3}$, calcium (total, bounded with protein and ultrafiltrated), inorganic phosphorus, magnesium and alkaline phosphatase activity and its isoenzymes in the blood of cows and their calves in the early postnatal period.

Studies were conducted in the cows of the Ukrainian Black-and-White dairy breed and calves obtained from them. The experiment was performed during the winter housing period in pilot farm «Pasichna» of Institute of forage and agricultural Podillya NAAS of Ukraine, located in the natural geographical areas of Podillya. The blood for tests was collected from the jugular vein before morning feeding in the $5^{\text {th }}-7^{\text {th }}$ day since calving. The blood from the calves was collected in the following dates: at $5^{\text {th }}-7^{\text {th }}$ days old and at 28-30 th days old. Vitamin D provision rate of animal organism was evaluated for the content of $25 \mathrm{OH} \mathrm{D}_{3}$ concentration in blood. The level of 25-hydroxycholecalciferol is considered as a total reflection of the endogenous formation of cholecalciferol in the skin and its receipts from feed or vitamin preparations. The concentration of $25 \mathrm{OHD}_{3}$ in the blood of the examined animals was detected by means of the enzymelinked immunoassay using the test system developed by the Immunodiagnostik. The method is based on the competitive binding of $25 \mathrm{OHD}_{3}$ serum and $25 \mathrm{OH} \mathrm{D}_{3}$-biotin with vitamin $\mathrm{D}_{3}$-binding protein (VDBP), that immobilized on 96-well immunological plates. The content of calcium (total, bounded with protein and ultrafiltrated), inorganic phosphorus, magnesium and alkaline phosphatase (ALP) activity were detected using the biological test kits produced by the Pliva Lachema firm (the Czech Republic).

The performed research reported that the content of 25-hydroxycholecalciferol in serum of calves at 5-7-days age old was in the range of 29 to $34 \mathrm{nmol} / \mathrm{l}$ and slightly increased for the 28-30-days. It was established the dynamics of changes in the content of total calcium and its fractions, inorganic phosphorus, magnesium and activity of alkaline phosphatase and its isoenzymes in calves blood from 5-7- to 28-30-day-olds. The concentration of 25-hydroxyvitamin $D_{3}$ in the blood of calves in the first days after birth was lower, and the concentration of calcium and inorganic phosphorus - higher compared with their values in the blood of mothers in the postpartum period. It was found that the activity of alkaline phosphatase in the calf serum was higher, compared with its value in the serum of mothers. The increase in activity of alkaline phosphatase in the calf serum is expressed to a greater extent due to its bone enzyme.

Key words: cows, calves, vitamin $D_{3}$, metabolism, blood, 25-hydroxycholecalciferol

\section{Вступ}

Умови годівлі і утримання тільних корів мають значний вплив на життєздатність новонароджених телят, їх фізіологічну зрілість, подальний ріст і розвиток та реалізацію генетичного потенціалу продуктивності. Важливе місце у забезпечені життєдіяльності телят у ранньому постнатальному періоді займає вітамін D. У молодняку BPX у віці 1-12 місяців легкі форми D-дефіцитного стану діагностують більш ніж у 40\%. Причому телята, що народилися восени і зимою, хворіють частіше (Levchenko et al., 1981; Levchenko, 2004; Maslova, 2005; Vlizlo, 2007).

На D-вітамінний статус організму в ранньому постнатальному періоді має безпосередній вплив забезпеченість їхніх матерів цим вітаміном та рівень його активних метаболітів у молозиві і молоці, яке споживає потомство (Horst and Reinhardt, 1983; Kurtyak and Yanovych, 2004; Van Saun, 2004; Luk'yanova, 2005).

Критерієм оцінки щодо потреби у вітаміні D, яку запропонували Horst R.L. і співавт. (Horst et al., 1936) $\epsilon$ концентрація 25-гідроксихолекальциферолу у крові. Рівень 25-гідроксихолекальциферолу вважається су- марним відображенням ендогенного утворення холекальциферолу в шкірі та його надходження із корму або вітамінних препатів.

Незважаючи на велику кількість робіт, що ведуться різними групами дослідників задля встановлення нормального рівня вітаміну D в крові тварин (Wagner et al., 2008), актуальним залишається питання щодо оптимального рівня вітаміну D в організмі телят $\mathrm{y}$ різні періоди їх росту і розвитку та впливу регіональних факторів і умов утримання корів на процеси засвоєння і трансформації холекальциферолу в їхнього потомства.

Метою роботи було дослідити вміст активного метаболіту вітаміну $\mathrm{D}_{3}-25-\mathrm{OHD}_{3}$, концентрації кальцію, фосфору, магнію та активності лужної фосфатази в крові корів та їхніх телят у ранній постнатальний період.

\section{Матеріал і методи досліджень}

Дослід проведено на високопродуктивних коровах-аналогах української чорно-рябої молочної породи у період сухостою і після отелення та отриманих 
від них телятах. Дослід проводили у зимовостійловий період у Державному підприємстві «Дослідне господарство» «Пасічна» Інституту кормів та сільського господарства Поділля НААН. До раціону годівлі корів входили корми, які традиційно використовуються в цьому господарствах. Він відповідав рівню молочної продуктивності корів і їх фізіологічному стану та загальноприйнятим нормам (Kalashnikov, 2003; Bohdanov, 2012).

Для біохімічних досліджень від корів брали кров 3 яремної вени на 5-7-й день після отелення. Кров від телят брали на 5-7-й і 28-30-й дні після народження. $\mathrm{У}$ крові визначали вміст 25-- $\mathrm{OD}_{3}$ імуноензимним методом ELISA, відповідно до протоколу для використання набору 25-Hydroxy Vitamin D «Immundiagnostik» (Kondrahin, 2004; Vlizlo, 2012). Вміст кальцію (загального, протеїнзв'язаного і ультрафільтрувального), фосфору неорганічного, магнію та активність лужної фосфатази (ЛФ) у сироватці крові визначали, використовуючи біотест-набори фірми «Pliva Lachema» (Чехія) (Vlizlo, 2012). Активність ізоензимів лужної фосфатази вивчали 3 використанням інгібіторів і розраховували згідно з методом, описаним в роботі (Vagner et al., 1981; Levchenko, 2010).

Статистичну обробку експериментальних даних проводили загальноприйнятими методами варіаційної статистики з вирахуванням середнього значення $(\mathrm{M})$ й похибки $( \pm \mathrm{m})$. Задля визначення достовірності відмінностей між одержаними величинами двох вибірок використовували t-критерій Стюдента. Результати вважали вірогідними при $\mathrm{P}<0,05-0,001$. Опрацювання і статистичну обробку одержаних цифрових даних виконували за допомогою програми Microsoft Excel.

\section{Результати та їх обговорення}

На основі проведених досліджень, ми встановили, що вміст 25-гідроксихолекальциферолу в сироватці крові телят у 28-30-денному віці суттєво не відрізнявся від його значення у 5-7-денному віці і становив у середньому 32,55 нмоль/л (табл.1). Також подібними були більшість показників мінерального обміну в крові телят від 5-7-денного до 28-30-денного віку. Зокрема, вміст кальцію загального на 28-30 день після народження у крові телят був нижчим, ніж у 5-7денному віці. При цьому вміст кальцію протеїнзв'язаного в 28-30-деному віці також був нижчим в 1,37 раза порівняно 3 його значенням у 5-7-денному віці (Р < 0,01). Вміст ультрафільтрувального кальцію у 28-30-денному віці, навпаки, мав тенденцію до зростання.

Таблиияя 1

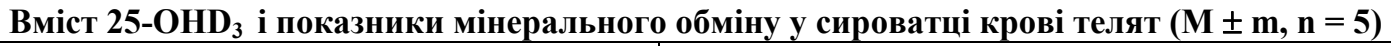

\begin{tabular}{|l|c|c|}
\hline \multicolumn{1}{|c|}{ Показники } & \multicolumn{2}{c|}{ Вік (дні) } \\
\cline { 2 - 3 } & $5-7$ & $28-30$ \\
\hline 25-ОНD, нмоль/л & $31,44 \pm 2,56$ & $2,55 \pm 2,05$ \\
\hline Кальцій загальний, ммоль/л & $2,65 \pm 0,08$ & $0,68 \pm 0,01 * *$ \\
\hline Кальцій протеїн-зв’язаний, ммоль/л & $0,93 \pm 0,03$ & $1,82 \pm 0,04$ \\
\hline Кальцій ультрафільтрувальний, ммоль/л & $1,72 \pm 0,05$ & $1,83 \pm 0,05$ \\
\hline Фосфор неорганічний, ммоль/л & $1,77 \pm 0,05$ & $0,82 \pm 0,02$ \\
\hline Магній, ммоль/л & $0,88 \pm 0,04$ & $177,04 \pm 8,65$ \\
\hline Лужна фосфатаза загальна (ЛФ), Од/л & $160,76 \pm 9,08$ & $38,35 \pm 1,74$ \\
\hline Кишковий ізоензим ЛФ, Од/л & $38,58 \pm 2,18$ & $137,13 \pm 6,46$ \\
\hline Кістковий ізоензим ЛФ, Од/л & $120,57 \pm 6,81$ & \\
\hline
\end{tabular}

Примітка: в цій таблиці ** - $\mathrm{P}<0,01$, порівняно з показниками в 5-7-денному віці

Із наведених у таблиці даних видно, що вміст неорганічного фосфору на 5-7-й день після народження становив всередньому 1,77 ммоль/л. У 30 -денному віці вміст неорганічного фосфору підвищився, проте різниці були невірогідними, порівняно із його значенням у 5-7-денному віці. Також не було істотних відмінностей у концентрації магнію в сироватці крові телят у 5-7- і 28-30-денному віці.

Активність лужної фосфатази та ії ізоензимів у сироватці крові телят від 5-7-денного до 28-30-денного віку змінювалась подібно до рівня 25-OHD 3 . У 5-7денному віці активність лужної фосфатази була у середніх межах 152-170 Од/л. У 30-денному віці активність ензиму дещо підвищилась відносно рівня у 5-7-денному віці. Це збільшення відбувалось, в основному, за рахунок кісткового ізоензиму лужної фосфатази.

У своїй роботі ми вважали за потрібне порівняти вміст $25 \mathrm{OHD}_{3}$ і показники мінерального обміну в крові корів і їхніх телят. На основі проведених досліджень ми встановили, що вміст $25 \mathrm{OHD}_{3}$ в крові телят на 5-7 день після народження був нижчим, а вміст кальцію і неорганічного фосфору - вищим, ніж у їхніх матерів на 5-7 день після отеленя (рис. 1, 2).

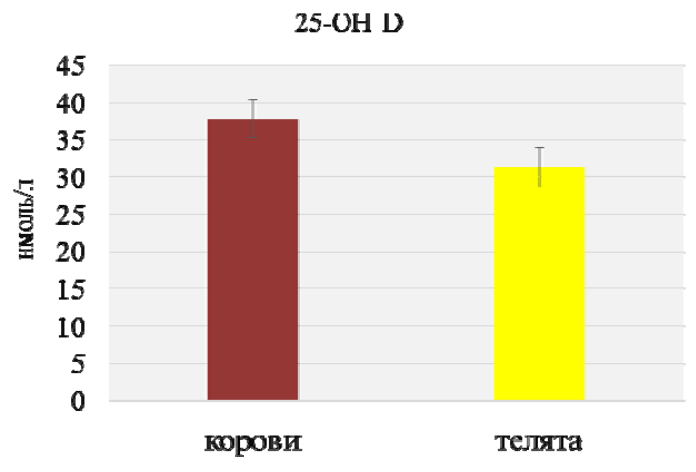

Рис. 1. Вміст 250HD у сироватці крові корів на 5-7-й день після отелення і їхніх телят у 5-7-добовому віці ( $\mathbf{M} \pm \mathbf{m}, \mathbf{n}=5)$

Виявлена нами нижча концентрація $25 \mathrm{OHD}_{3}$ в крові новонароджених телят порівняно з його вмістом 
у їх матерів на 5-7-й день після отелення, очевидно, зумовлена тим, що активність 25-гідроксилази у печінці новонароджених телят є дуже низькою (Nonnecke et al., 2009), i концентрація 25-гідроксихолекальциферолу в крові телят у перші дні після народження залежить від вмісту цього метаболіту у крові матерів, i, відтак, у випоюваному молозиві.

Висока концентрація Са в крові телят у перші дні після народження, ймовірно, може бути результатом впливу високої концентрації $1,25(\mathrm{OH})_{2} \mathrm{D}$ у крові матеpi на плацентарний транспорт Са, що підтверджено дослідженнями на вівцях (Durand et al., 2008).
Із наведених на рисунку 2 даних видно, що вміст неорганічного фосфору на 5-7-й день після народження був вищим, ніж його рівень у сироватці крові їхніх матерів, і становив $1,77 \pm 0,05$ ммоль/л. При цьому встановлено, що активність лужної фосфатази у сироватці крові телят була вищою, порівняно до іiі значення у сироватці крові матерів. Збільшення активності лужної фосфатази у сироватці крові телят виражено більшою мірою за рахунок її кісткового ензимy.

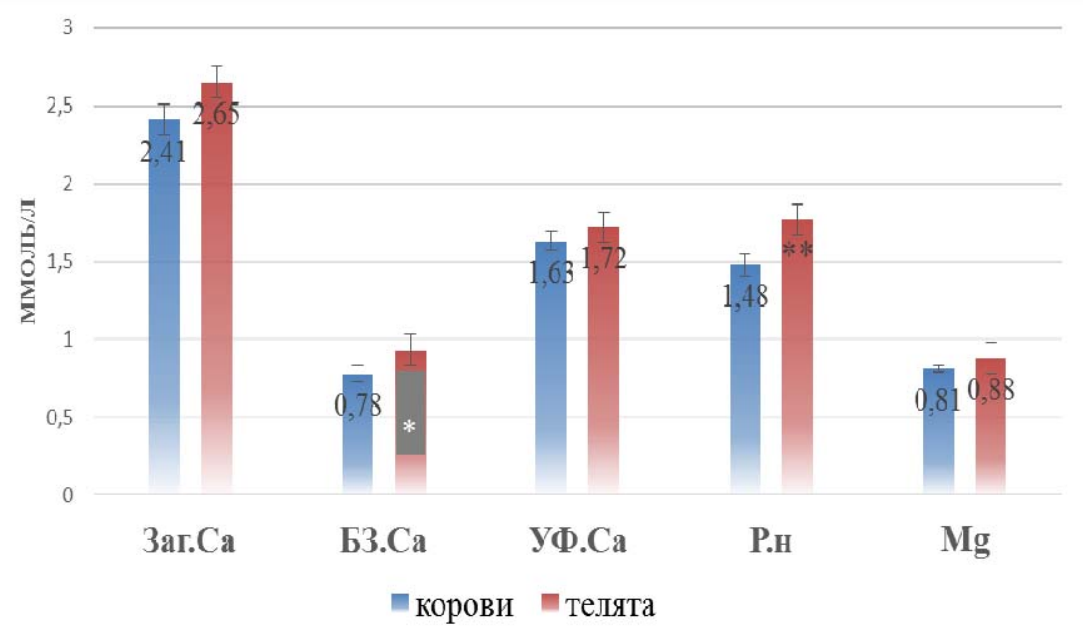

Рис. 2. Показники мінерального обміну у сироватці крові корів на 5-7-й день після отелення і їхніх телят у 5-7-добовому віці $(\mathbf{M} \pm \mathbf{m}, \mathbf{n}=\mathbf{5})$

\section{Висновки}

Отримані дані про динаміку змін біохімічних показників у крові телят від народження до місячного віку, а також результати про нижчий вміст 25-OHD 3 i вищий вміст кальцію i неорганічного фосфору та вищу активність лужної фосфатази в сироватці крові телят 5-7-денного віку порівнянно зі значеннями цих показників у сироватці крові їхніх матерів на 5-7-й день після отелення дають підставу стверджувати про вплив віку i фізіологічного стану на показники Dвітамінного і мінерального статусу в організмі великої рогатої худоби.

\section{Бібліографічні посилання}

Levchenko, V.I. (2004). Klinichna diahnostyka vnutrishnikh khvorob tvaryn. Bila Tserkva (in Ukrainian).

Vlizlo, V.V. (2007). Biokhimichni osnovy normuvannya vitaminnoho zhyvlennya koriv. Zhyrorozchynni vitaminy. Biolohiya tvaryn. $9(1-2), 25-42$ (in Ukrainian).

Levchenko, V.I., Tykhonyuk, L.A., Apukhovs'ka, L.I. (1981). Diahnostyka rannikh form D-hipovitaminozu $\mathrm{v}$ telyat za vmistom fosforu i 2,3dyfosfohlitseratu $\mathrm{v}$ erytrotsytakh. Visnyk ahrar.nauky. 9, 73-76 (in Ukrainian).

Maslova, T.V. (2005). Jetiologicheskie faktory razvitija D-deficitnogo sostojanija u teljat. Uspehi sovremennogo estestvoznanija. 10, 68 (in Russian).
Kurtyak, B.M., Yanovych, V.H. (2004). Zhyrorozchynni vitaminy u veterynarniy medytsyni i tvarynnytstvi. L'viv: Triada plyus (in Ukrainian).

Luk'yanova, E.M. (2005). Vytamyn D y eho rol' v obespechenyy zdorov'ya detey y beremennykh zhynshchyn. K.: Yekspert B (in Ukrainian).

Van Saun, R.J. (2004). Vitamin D - responsive rickets in neonatal lambs. Can Vet J., 45, 841-844.

Horst, R.L., Reinhardt, T.A. (1983). Vitamin D metabolism in ruminants and its relevance to the periparturient cow. J. Dairy Sci. 66(4), 661-678.

Horst, R.L., Goff, J.P., Reinhardt, T.A. (1936). Calcium and vitamin D metabolism in the dairy cow. J. Dairy Sci. 77, 1936-1951.

Wagner, C.L., Taylor, S.N., Hollis, B.W. (2008). Does vitamin $\mathrm{D}$ make the world go «round». Breastfeed. Med. 3, 239-250.

Kalashnikov, A.P. (2003). Normy i raciony kormlenija sel'skohozjajstvennyh zhivotnyh : spravochnoe posobie. M: Agropromizdat (in Russian).

Bohdanov, H.O. (2012). Normy i ratsiony povnotsinnoyi hodivli vysokoproduktyvnoyi velykoyi rohatoyi khudoby: dovidnyk-posibnyk. K.: Ahrarna nauka (in Ukrainian).

Vlizlo, V.V. (2012). Laboratorni metody doslidzhen' u biolohiyi, tvarynnytstvi ta veterynarniy medytsyni: dovidnyk. L'viv: Spolom (in Ukrainian).

Kondrahin, I.P. (2004). Metody veterinarnoj klinicheskoj laboratornoj diagnostiki: spravochnik. M.: KolosS (in Russian). 
Vagner, V.K., Putilin, V.M., Harabuga, G.G. (1981). Metody i rezul'taty issledovanija izofermentov (kishechnoj i pechenochnoj frakcij) syvorotochnoj shhelochnoj fosfatazy pri ostryh hirurgicheskih zabolevanijah organov brjushnoj polosti. Vopr. med. himii. 27(6), 752-754 (in Russian).

Levchenko, V.I. (2010). Metody laboratornoyi klinichnoyi diahnostyky khvorob tvaryn. K.: Ahrarna osvita (in Ukrainian).

Nonnecke, B.J., Reinhardt, T.A., Waters, W.R. (2009). Short communication: The preruminant calf as a mod- el for characterizing the effects of vitamin D status in the neonate. J Dairy Sci. 92(11), 5692-5696.

Durand, D., Braithwaite, G.D., Baler, J.P. (1983). The effect of la-hydroxycholecalciferol on the placental transfer of calcium and phosphate in sheep. Br. J. Nutr. 49, 475.

Received 29.09.2017 Received in revised form 18.10.2017 Accepted 23.10.2017 